\title{
Analisis Silhouette Coefficient pada 6 Perhitungan Jarak K-Means Clustering
}

\author{
Silhouette Coefficient Analysis in 6 Measuring Distances of K-Means Clustering
}

\author{
Rahmatina Hidayati ${ }^{1}$, Anis Zubair ${ }^{2}$, Aditya Hidayat Pratama ${ }^{3}$, Luthfi Indana ${ }^{4}$ \\ 1,2,3,4Program Studi Sistem Informasi, Fakultas Teknologi Informasi, \\ Universitas Merdeka Malang \\ E-mail: ${ }^{1}$ rahmatina.hidayati@unmer.ac.id, ${ }^{2}$ anis.zubair.2@unmer.ac.id, \\ ${ }^{3}$ aditya.hidayat@unmer.ac.id, ${ }^{4}$ luthfi.indana@unmer.ac.id
}

\begin{abstract}
Abstrak
Clustering merupakan proses pengelompokan sekumpulan data ke dalam klaster yang memiliki kemiripan. Kemiripan dalam satau klaster ditentukan dengan perhitungan jarak. Untuk melihat perfoma beberapa perhitungan jarak, dalam penelitian ini penulis menguji pada 6 data yang memiliki atribut berbeda, yakni 2, 3, 4, dan 6 atribut. Dari hasil uji perbandingan rumus jarak pada K-Means clustering menggunakan Silhouette coefficient dapat disimpulkan bahwa: 1) Chebyshev distance memiliki performa yang stabil baik untuk data dengan sedikit atribut maupun banyak. 2) Average distance memiliki hasil Silhouette coefficient paling tinggi dibandingkan dengan pengukuran jarak lain untuk data yang memiliki outliers seperti data 3.3) Mean Character Difference mendapatkan hasil yang baik hanya untuk data dengan sedikit atribut. 4) Euclidean distance, Manhattan distance, dan Minkowski distance menghasilkan nilai baik untuk data yang memiliki sedikt atribut, sedangkan untuk data yang banyak atribut mendapatkan nilai cukup yang mendekati 0,5.
\end{abstract}

Kata kunci: K-Means, Clustering, Silhouette Coefficient

\begin{abstract}
Clustering is the process of grouping a set of data into clusters that have similarities. The similarity in a cluster is determined by calculating the distance. To see the performance of some distance calculations, in this study the authors tested 6 data which had different attributes, namely 2, 3, 4, and 6 attributes. From the results of the comparison test for the distance formula on K-Means clustering using the Silhouette coefficient, it can be concluded that: 1) Chebyshev distance has stable performance both for data with few and many attributes. 2) Average distance has the highest Silhouette coefficient result compared to other distance measurements for data that has outliers such as data 3. 3) Mean Character Difference gets good results only for data with few attributes. 4) Euclidean distance, Manhattan distance, and Minkowski distance produce good values for data that have few attributes, while data with many attributes get a sufficient value that is close to 0.5 .
\end{abstract}

Keywords: K-Means, Clustering, Silhouette Coefficient

\section{PENDAHULUAN}

Clustering merupakan proses pengelompokan sekumpulan data ke dalam klaster yang memiliki kemiripan, di mana kesamaan dalam satu klaster dimaksimalkan, sedangkan kesamaan di luar klaster diminimalkan dengan perhitungan jarak. Salah satu metode yang digunakan untuk menemukan klaster dalam data adalah $K$-Means clustering yang mana k mempresentasikan jumlah klaster[1].

Penelitian [2] membandingkan Euclidean distance, Manhattan distance, dan Minkowski distance dalam pengukuran jarak K-Means. Berdasarkan uji homogenitas klaster dengan Silhouette coefficient, Minkowski distance mendapatkan nilai tertinggi, sedangkan Euclidean 
distance memperoleh akurasi terbaik dengan Chi-squre. Penelitian [3] menguji Euclidean distance, Manhattan distance, dan Chebyshev distance dalam pengelompokan member di salah satu tempat fitenes menggunakan algoritma K-Means. Hasilnya, Chebyshev distance memiliki nilai Silhouette coefficient yang lebih baik dibandingkan Euclidean distance dan Manhattan distance.

Berdasarkan uji Silhouette coefficient pada penelitian [4], Euclidean distance memperoleh nilai tertinggi sebesar 0,64018 dibandingkan Manhattan distance, dan Cosine distance. Pada penelitian [5] Euclidean distance memiliki kinerja lebih baik dibandingkan dengan Manhattan distance berdasarkan evaluasi Davies Bouldin Index (DBI).

Penelitian [6] menerapkan $K$-Means clustering pada data Ujian Nasional SMP tahun 2018/2019. Persamaan jarak yang digunakan adalah Euclidean distance. Hasil evaluasi dengan Silhouette mendapatkan nilai 0,464 yang berarti struktur pengelompokannya lemah. Sedangkan pada penelitian [7], penggunaan Euclidean distance untuk text mining dokumen skripsi menghasilkan Silhouette tertinggi 0,12 yang menandakan pengelompokannya tidak terstruktur. Hal ini berbeda dengan hasil pebelitian [8] di mana penggunaan Euclidean distance dalam $K$ Means clustering untuk pengelompokan pelanggan potensial berstruktur kuat dengan nilai Silhouette 0,85 .

Penelitian [9] menguji Euclidean distance pada data evaluasi pembelajaran. Hasil terbaik didapat dengan nilai k=5 yang memperoleh Silhouette coefficient $>0,5$. Pada penelitian [10], performa Euclidean distance lebih optimal dibandingkan dengan Manhattan distance untuk data penentuan promosi.

Berdasarkan studi literatur dari beberapa penelitian sebelumnya, persamaan perhitungan jarak yang sering digunakan adalah Euclidean distance. Analisis yang dihasilkan hanya berupa pemilihan jumlah $\mathrm{k}$ optimal. Sedangkan untuk sebagian penelitian yang lain melakukan perbandingan Euclidean distance, Manhattan distance, Chebyshev distance, dan Minkowski distance. Perbandingan rumus jarak tersebut dilakukan hanya untuk satu data.

Penelitian [11] menguji 3 perhitungan jarak K-Means clustering pada 3 data yang memiliki atribut berbeda. Pada pengujian data dengan 4 atribut, Euclidean distance memperoleh nilai Purity terbaik. Sedangkan pada data dengan 2 dan 6 atribut, Carberra Purity mendapatkan hasil terbaik dibandingkan Euclidean Purity dan City Block Purity.

Pada penelitian ini, penulis juga akan menguji beberapa perhitungan jarak pada 6 data yang memiliki atribut berbeda, yakni 2, 3, 4, dan 6 atribut. Persamaan jarak tersebut antara lain Euclidean distance, Manhattan distance (City Block), Chebyshev distance, Minkowski distance, Average distance, dan Mean Character Difference. Untuk mengevaluasi hasil pengelompokan, penulis menggunakan rumus Silhouette coefficient. 


\section{METODE PENELITIAN}

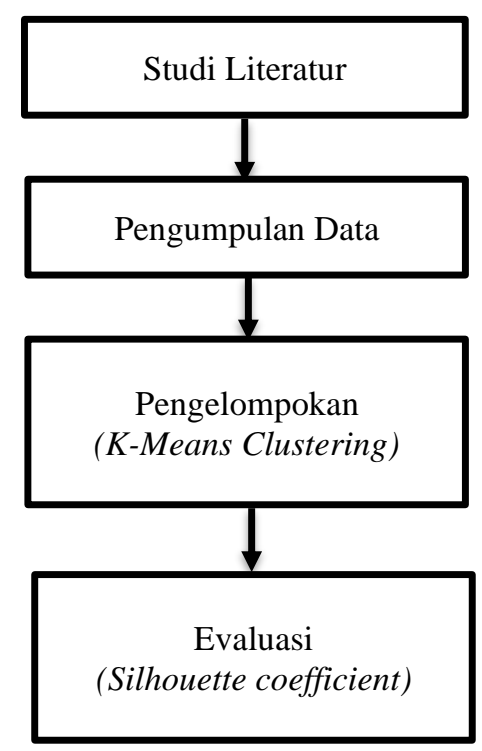

Gambar 1 Tahapan Penelitian Analisis Silhouette Coefficient pada 6 Perhitungan Jarak K-Means Clustering

\subsection{Pengumpulan data}

Dalam penelitian ini data yang digunakan terdiri dari 6 data yang memiliki jumlah atribut berbeda. Data tersebut diperoleh dari Badan Pusat Statisik Indonesa, Badan Pusat Statistik Jawa Timur, dan situs resmi Provinsi Jawa Timur. Rincian dari data tersebut ditampilkan pada Tabel 1.

Tabel 1 Rincian Data Penelitian

\begin{tabular}{|c|c|c|c|}
\hline No. & Data & Atribut & Sumber \\
\hline 1. & $\begin{array}{c}\text { Presentase Rumah Tangga Mengakses Internet } \\
\text { dalam } 3 \text { Bulan Terakhir }\end{array}$ & Tahun 2018-2019 & hlm 449 [12] \\
\hline 2. & $\begin{array}{c}\text { Produksi Tanaman Sayuran Semusim Menurut } \\
\text { Jenis Tanaman (ton) }\end{array}$ & Tahun 2018-2019 & hlm 281 [12] \\
\hline 3. & $\begin{array}{c}\text { Angka Partisipaso Sekolah (APS) menurut } \\
\text { Kota/Kab. Dan Kelompok Usia Sekolah Tahun } \\
2019\end{array}$ & $\begin{array}{l}\text { Usia 7-12 Tahun, usia 13-15 tahun, usia } \\
\text { 16-18 tahun }\end{array}$ & hlm 39 [13] \\
\hline 4. & $\begin{array}{c}\text { Resiko Penularan Covid-19 di Provinsi Jawa } \\
\text { Timur }\end{array}$ & $\begin{array}{l}\text { Pasien positif yang masih aktif, pasien } \\
\text { meninggal, dan suspek, probable }\end{array}$ & [14] \\
\hline 5. & $\begin{array}{c}\text { Jumlah Des/Kel yang Memiliki Fasilitas } \\
\text { Sekolah Menurut Provinsi dan Tingkat } \\
\text { Pendidikan Tahun } 2019\end{array}$ & SD, SMP, SMA, SMK & hlm 198-199 [12] \\
\hline 6. & $\begin{array}{c}\text { Jumlah Des/Kel yang Memiliki Sarana } \\
\text { Kesehatan Menurut Provinsi Tahun } 2019\end{array}$ & $\begin{array}{l}\text { Rumah Sakit, Rumah Sakit Bersalin, } \\
\text { Poliklinik, Puskesmas, Puskesmas } \\
\text { Pembantu, Apotek }\end{array}$ & hlm 200-201 [12] \\
\hline
\end{tabular}

\subsection{Metode}

\section{A. K-Means Clustering}

Clustering merupakan proses pengelompokan sekumpulan data ke dalam klaster yang memiliki kemiripan. Salah satu metode yang digunakan untuk menemukan klaster dalam data adalah K-Means clustering yang mana k mempresentasikan jumlah klaster [1]. Suatu data dikelompokkan ke dalam satu klaster berdasarkan kemiripan atribut yang dimiliki. Kemiripan ini bisa diketahui dengan menerapkan pengukuran jarak. Metode perhitungan jarak dalam penelitian ini antara lain [15]:

\section{1) Euclidean Distance}


Euclidean distance merupakan perhitungan jarak yang paling umum digunakan. Untuk 2 titik data $\mathrm{x}$ dan y dalam d-dimensi data, perhitungan jarak menggunaka Euclidean distance dirumuskan dengan Persamaan (1):

di mana,

$$
d_{e u c}(x, y)=\sqrt{\sum_{j=1}^{d}\left(x_{j}-y_{j}\right)^{2}}
$$

$x_{j}, y_{j}=$ nilai dari $\mathrm{j}$ atribut

2) Manhattan Distance

Manhattan distance yang disebut juga city block distance didefinisikan sebagai jumlah jarak dari semua atribut.

$$
d_{\text {man }}(x, y)=\sum_{j=1}^{d}\left|x_{j}-y_{j}\right|
$$

\section{3) Chebyshev Distance}

Chebyshev disebut juga Maximum distance karena dalam penerapannya mencari nilai maksimum dari selisih jarak titik data $\mathrm{x}$ dan y di dimensi ruang d. Jarak maksimum tersebut ditulis seperti Persamaan (3):

$$
d_{\text {Che }}(x, y)=\max _{1 \leq k \leq d}\left|x_{j}-y_{j}\right|
$$

\section{4) Minkowski Distance}

Euclidean distance, Manhattan distance, dan Chebyshev distance merupakan tiga kasus khusus dari Minkowski distance yang didefinisikan seperti Persamaan (4):

$$
d_{\text {minw }}(x, y)=\left(\sum_{j=1}^{d}\left|x_{j}-y_{j}\right|^{r}\right)^{\frac{1}{r}}, r \geq 1
$$

Jika nilai $\mathrm{r}=2,1$, dan maka akan didapat Euclidean distance, Manhattan distance, dan Chebyshev distance. Dalam penelitian ini, menggunakan nilai $\mathrm{r}=1,5$.

\section{5) Average Distance}

Average distance merupakan modifikasi dari Euclidean distance untuk memperbaiki keurangan, di mana dua titik data yang tidak mempunyai nilai atribut biasanya memiliki jarak lebih kecil dibandingkan pasangan titik data yang berisi nilai atribut serupa.

$$
d_{A v e}(x, y)=\frac{1}{d} \sqrt{\sum_{j=1}^{d}\left(x_{j}-y_{j}\right)^{2}}
$$

6) Mean Character Difference

Mean character difference merupakan rata-rata dari Manhattan distance.

$$
d_{\text {mean }}(x, y)=\frac{1}{d} \sum_{j=1}^{d}\left|x_{j}-y_{j}\right|
$$

\section{B. Silhouette Coefficient}

Untuk melihat kualitas hasil pengelompokan masing-masing perhitungan jarak, maka perlu dilakukan uji homogenitas. Pengujian dilakukan setelah mencapai konvergensi 0 di mana hasil pengelompokan terakhir sama dengan pengelompokan sebelumnya. Dengan kata lain, tidak ada data yang berpindah klaster. Pengujian dihitung menggunakan persamaan Silhouette coefficient. Langkah dalam menghitung Silhouette coefficient di mulai dengan mencari jarak ratak-rata data ke- $i$ dengan semua data di klaster yang sama, di sini kita asumsikan data ke- $i$ berada di klaster A. Rumus dari $a(i)$ ditulis dalam Persamaan (7) [16]. 
di mana,

$$
a(i):=\frac{1}{|A|-1} \sum_{j \in A, j \neq 1} d(i, j)
$$

$\mathrm{A}=$ banyaknya data di klaster $\mathrm{A}$

Selanjutnya menghitung nilai $b(i)$ yang merupakan nilai minimum dari jarak rata-rata data ke- $i$ dengan semua data di klaster berbeda. Sekarang, mari asumsikan klaster berbeda selain A dengan klaster C. Maka, perhitungan jarak rata-rata data ke- $i$ dengan semua data di klaster $\mathrm{C}$ ditulis sebagai berikut:

$$
d(i, C):=\frac{1}{|C|} \sum_{j \in C} d(i, j)
$$

di mana $\mathrm{C}=$ banyaknya data di klaster $\mathrm{C}$

Setelah menghitung $d(i, C)$ untuk semua klaster $\mathrm{C} \neq \mathrm{A}$, selanjutnya memilih nilai jarak paling minimum sebagai nilai $b(i)$.

$$
b(i):=\min _{C \neq A} d(i, j)
$$

Jika klaster B memiliki nilai jarak minimum, maka $d(i, B)=b(i)$ yang disebut sebagai tetangga dari data ke- $i$ dan merupakan klaster terbaik kedua untuk data ke- $i$ setelah klaster A. Setelah $a(i)$ dan $b(i)$ diketahui, maka proses terakhir menghitung Silhouette coefficient [16].

$$
s(i)=\frac{b(i)-a(i)}{\max \{a(i)-b(i)\}}
$$

Nilai $s(i)$ berada antara -1 dan 1, di mana setiap nilai diiinterpretasi sebagai berikut: $s(i) \approx 1 \Rightarrow$ data ke- $i$ digolongkan dengan baik (dalam A)

$s(i) \approx 0 \Rightarrow$ data ke- $i$ berada di tengah antara dua klaster (A dan B)

$s(i) \approx-1=>$ data ke- $i$ digolongkan dengan lemah (dekat ke klaster B daripada A)

Penafsiran nilai Silhouette coefficient ditunjukkan dalam Tabel 2 [16].

Tabel 2 Interpretasi Nilai Silhouete Coefficient

\begin{tabular}{|c|l|}
\hline Silhouette Coefficient & \multicolumn{1}{c|}{ Interpretasi } \\
\hline $0.71-1.00$ & Struktur yang dihailkan kuat \\
\hline $0.51-0.70$ & Struktur yang dihasilkan baik \\
\hline $0.26-0.50$ & Struktur yang dihasilkan lemah \\
\hline$\leq 0.25$ & Tidak tersruktur \\
\hline
\end{tabular}

\section{HASIL DAN PEMBAHASAN}

Penelitian ini menggunakan 6 data dengan jumlah atribut berbeda yakni 2, 3, 4, dan 6 atribut. Salah satu data yang memiliki 4 atribut adalah data jumlah desa/kelurahan yang memiliki fasilitas sekolah menurut provinsi dan tingkat pendidikan tahun 2019 yang ditampilkan pada Tabel 3. 
Tabel 3 Jumlah Des/Kel yang Memiliki Fasilitas Sekolah

\begin{tabular}{|c|c|c|c|c|c|}
\hline No. & Provinsi & SD & SMP & SMA & SMK \\
\hline 1 & Aceh & 3475 & 1405 & 716 & 190 \\
\hline 2 & Sumatera Utara & 5039 & 2280 & 1094 & 678 \\
\hline 3 & Sumatera Barat & 1243 & 793 & 410 & 173 \\
\hline 4 & Riau & 1816 & 1187 & 588 & 254 \\
\hline 5 & Jambi & 1471 & 770 & 359 & 157 \\
\hline 6 & Sumatera Selata & 2985 & 1333 & 639 & 233 \\
\hline 7 & Bengkulu & 1187 & 477 & 186 & 100 \\
\hline 8 & Lampung & 2532 & 1429 & 654 & 397 \\
\hline 9 & Kepulauan Bang & 388 & 206 & 80 & 49 \\
\hline 10 & Kepulauan Riau & 396 & 244 & 121 & 65 \\
\hline 11 & DKI Jakarta & 264 & 257 & 215 & 211 \\
\hline 12 & Jawa Barat & 5948 & 4187 & 2022 & 1989 \\
\hline 13 & Jawa Tengah & 8443 & 3607 & 1266 & 1212 \\
\hline 14 & DI Yogyakarta & 437 & 316 & 144 & 147 \\
\hline 15 & Jawa Timur & 8443 & 4762 & 2420 & 1586 \\
\hline 16 & Banten & 1541 & 1235 & 689 & 519 \\
\hline 17 & Bali & 709 & 321 & 144 & 124 \\
\hline 18 & Nusa Tenggara B & 1129 & 875 & 548 & 269 \\
\hline 19 & Nusa Tenggara $\mathrm{T}$ & 3202 & 1613 & 575 & 280 \\
\hline 20 & Kalimantan Bara & 2052 & 1117 & 403 & 171 \\
\hline 21 & Kalimantan Teng & 1553 & 792 & 277 & 117 \\
\hline 22 & Kalimantan Selat & 1867 & 769 & 305 & 104 \\
\hline 23 & Kalimantan Timu & 984 & 541 & 234 & 153 \\
\hline 24 & Kalimantan Utar & 316 & 154 & 59 & 30 \\
\hline 25 & Sulawesi Utara & 1556 & 725 & 239 & 172 \\
\hline 26 & Sulawesi Tengah & 1925 & 945 & 336 & 168 \\
\hline 27 & Sulawesi Selatan & 2947 & 1739 & 770 & 337 \\
\hline 28 & Sulawesi Tengga & 1871 & 887 & 386 & 156 \\
\hline 29 & Gorontalo & 655 & 361 & 107 & 52 \\
\hline 30 & Sulawesi Barat & 630 & 404 & 156 & 111 \\
\hline 31 & Maluku & 1089 & 597 & 259 & 97 \\
\hline 32 & Maluku Utara & 1093 & 629 & 292 & 140 \\
\hline 33 & Papua Barat & 928 & 290 & 126 & 48 \\
\hline 34 & Papua & 2147 & 612 & 236 & 126 \\
\hline
\end{tabular}

\section{Langkah-langkah K-Means Clustering:}

(1) Tentukan jumlah $\mathrm{k}$

Pada penelitian ini, k untuk seluruh data ditetapkan sama dengan 3.

(2) Tentukan nilai centroid awal

Nilai centroid didapat berdasarkan distribusi data. Tabel 4 menampilkan centroid awal dari data fasilitas sekolah di mana klaster $1=$ nilai maksimu, klaster $2=$ nilai rata-rata, dan klaster 3 = nilai minimum. 
Tabel 4 Nilai Centroid Awal

\begin{tabular}{|c|c|c|c|c|}
\hline & SD & SMP & SMA & SMK \\
\hline c1 & 8443 & 4762 & 2420 & 1989 \\
\hline c2 & 2125,324 & 1113,5 & 501,6176 & 312,2059 \\
\hline c3 & 264 & 154 & 59 & 30 \\
\hline
\end{tabular}

Perhitungan jarak titik data ke-1 dengan centroid klaster 1 menggunakan Persamaan (1) sampai Persamaan (6) dinyatakan sebagai berikut:

$$
\begin{aligned}
& d_{e u c}(x, y)=\sqrt{(3475-8443)^{2}+(1405-4762)^{2}+(716-2420)^{2}+(190-1989)^{2}} \\
& =6487,72 \\
& d_{\text {man }}(x, y)=|3475-8443|+|1405-4762|+|716-2420|+|190-1989| \\
& =11828 \\
& d_{C h e}(x, y)=\max |3475-8443|+\max |1405-4762|+\max |716-2420|+\max |190-1989| \\
& =4968 \\
& d_{\text {minw }}(x, y)=\left(|3475-8443|^{1,5}+|1405-4762|^{1,5}+|716-2420|^{1,5}+|190-1989|^{1,5}\right)^{1 / 1,5} \\
& =7818,369 \\
& d_{\text {Ave }}(x, y)=\frac{1}{34} \sqrt{(3475-8443)^{2}+(1405-4762)^{2}+(716-2420)^{2}+(190-1989)^{2}} \\
& =1052,447 \\
& d_{\text {mean }}(x, y)=\frac{1}{34}(|3475-8443|+|1405-4762|+|716-2420|+|190-1989|) \\
& =311,263
\end{aligned}
$$

Lakukan perhitungan jarak titik data ke-1 dengan nilai centroid klaster 2 dan juga klaster 3. Serta lakukan perhitungan serupa untuk titik data ke-2 sampai titik data ke-34. Setelah mengetahui jarak data dengan centroid semua klaster, selanjutnya mengelompokkan data ke dalam klaster yang memiliki hasil jarak minimum.

(3) Update nilai centroid

Nilai centroid baru merupakan rata-rata nilai data yang berada di tiap klaster. Pada hasil perhitungan Euclidean distance, Provinsi Jawa Barat, Jawa Tengah, dan Timur berada dalam klaster 1. Jadi, perhitungan centroid baru klaster 1 dilakukan dengan rumus berikut: 


$$
\begin{aligned}
& c 1_{S D}=\frac{1}{3}(5948+8443+8443)=7611,333 \\
& c 1_{S M P}=\frac{1}{3}(4178+3607+4762)=4185,333 \\
& c 1_{S M A}=\frac{1}{3}(2022+1266+2420)=1902,667 \\
& c 1_{S M K}=\frac{1}{3}(1989+1212+1586)=1595,667
\end{aligned}
$$

Lakukan perhitungan yang sama untuk centroid kedua pada klaster 2 dan 3. Setelah mendapatkan nilai centroid baru, selanjutnya menghitung jarak kembali. Proses ini dilakukan berulang sampai mencapai konvergensi 0 . Tabel 5 menampilkan jumlah data masing-masing klaster pada pengelompokan terakhir.

Tabel 5 Jumlah data Masing-Masing Klaster

\begin{tabular}{|l|c|c|c|}
\hline \multicolumn{1}{|c|}{ Measure Distance } & C1 & C2 & C3 \\
\hline Euclidean & 3 & 13 & 18 \\
\hline Manhattan & 3 & 9 & 22 \\
\hline Chebyshev & 4 & 14 & 16 \\
\hline Minkowski & 3 & 12 & 19 \\
\hline Average & 3 & 13 & 18 \\
\hline Mean Character Difference & 3 & 20 & 11 \\
\hline
\end{tabular}

(4) Uji Homogenitas

Untuk melihat kemiripan data yang tergabung ke dalam satu kelompok, maka perlu dilakukan uji homogenitas. Pengujian ini menggunakan rumus Silhouette coefficient. Hasil

\begin{tabular}{|c|c|c|c|c|c|}
\hline $\mathbf{a}(1)$ & 1358,78 & $\mathbf{b}(\mathbf{1})$ & 2792,73 & $s(\mathbf{1})$ & 0,5135 \\
\hline $\mathbf{a}(2)$ & 2991,21 & b(2) & 3619,69 & $\mathrm{~s}(2)$ & 0,1736 \\
\hline $\mathbf{a}(3)$ & 644,96 & $b(3)$ & 1472,11 & $\mathbf{s}(3)$ & 0,5619 \\
\hline $\mathbf{a}(4)$ & 1048,72 & b(4) & 1240,08 & $s(4)$ & 0,1543 \\
\hline $\mathbf{a}(5)$ & 744,19 & b(5) & 1291,30 & $\mathrm{~s}(5)$ & 0,4237 \\
\hline $\mathbf{a}(6)$ & 1056,24 & $b(6)$ & 2305,37 & $s(6)$ & 0,5418 \\
\hline $\mathbf{a}(7)$ & 544,66 & $b(7)$ & 1688,09 & $s(7)$ & 0,6774 \\
\hline $\mathbf{a}(8)$ & 977,17 & b(8) & 1967,49 & $\mathbf{s}(\mathbf{8})$ & 0,5033 \\
\hline $\mathbf{a}(9)$ & 672,95 & $\mathbf{b}(\mathbf{9})$ & 2507,73 & $\mathbf{s}(9)$ & 0,7317 \\
\hline $\mathbf{a}(10)$ & 646,81 & $\mathbf{b}(\mathbf{1 0})$ & 2475,57 & $\mathbf{s}(\mathbf{1 0})$ & 0,7387 \\
\hline $\mathbf{a}(11)$ & 755,59 & $b(11)$ & 2565,05 & $\mathbf{s}(\mathbf{1 1})$ & 0,7054 \\
\hline $\mathbf{a}(12)$ & 2701,90 & $b(12)$ & 5025,14 & $\mathrm{~s}(12)$ & 0,4623 \\
\hline $\mathbf{a}(13)$ & 2228,24 & b(13) & 6433,75 & $\mathbf{s}(\mathbf{1 3})$ & 0,6537 \\
\hline$a(14)$ & 607,77 & b(14) & 2400,40 & $s(14)$ & 0,7468 \\
\hline $\mathbf{a}(15)$ & 2148,65 & $b(15)$ & 7206,02 & $s(15)$ & 0,7018 \\
\hline
\end{tabular}
perhitungan nilai (ai), $b(i)$, dan Silhouette coefficient $(s)$ masing-masing data ditunjukkan di Tabel 6.

Tabel 6 Nilai $a(i), b(i)$, dan $s(i)$ Euclidean Distance 
Techno.COM, Vol. 20, No. 2, Mei 2021: 186-197

\begin{tabular}{|c|c|c|c|c|c|}
\hline$a(16)$ & 1306,97 & $b(16)$ & 1202,43 & $s(16)$ & $-0,0800$ \\
\hline $\mathbf{a}(17)$ & 505,86 & $\mathbf{b}(17)$ & 2163,15 & $\mathbf{s}(17)$ & 0,7661 \\
\hline$a(18)$ & 728,33 & b(18) & 1548,70 & $s(18)$ & 0,5297 \\
\hline $\mathbf{a ( 1 9 )}$ & 1201,54 & b(19) & 2604,78 & $\mathbf{s}(19)$ & 0,5387 \\
\hline $\mathbf{a}(20)$ & 947,40 & $b(20)$ & 1344,39 & $s(20)$ & 0,2953 \\
\hline $\mathbf{a}(21)$ & 803,63 & $\mathbf{b}(21)$ & 1237,18 & $\mathrm{~s}(21)$ & 0,3504 \\
\hline $\mathbf{a}(22)$ & 1112,22 & $\mathbf{b}(22)$ & 1039,55 & $\mathrm{~s}(22)$ & $-0,0653$ \\
\hline $\mathbf{a}(23)$ & 482,66 & $\mathbf{b}(23)$ & 1814,32 & $\mathbf{s}(\mathbf{2 3})$ & 0,7340 \\
\hline$a(24)$ & 752,71 & $b(24)$ & 2598,28 & $s(24)$ & 0,7103 \\
\hline $\mathbf{a}(25)$ & 788,54 & $\mathbf{b}(\mathbf{2 5})$ & 1265,78 & $\mathbf{s}(25)$ & 0,3770 \\
\hline$a(26)$ & 1004,24 & $b(26)$ & 1150,35 & $s(26)$ & 0,1270 \\
\hline $\mathbf{a}(27)$ & 1164,48 & b(27) & 2483,86 & $s(27)$ & 0,5312 \\
\hline $\mathrm{a}(28)$ & 1035,48 & $\mathbf{b}(28)$ & 1085,64 & $\mathbf{s}(28)$ & 0,0462 \\
\hline $\mathrm{a}(29)$ & 518,08 & b(29) & 2205,90 & $\mathrm{~s}(29)$ & 0,7651 \\
\hline $\mathrm{a}(30)$ & 512,05 & $b(30)$ & 2195,17 & $\mathrm{~s}(30)$ & 0,7667 \\
\hline $\mathbf{a}(31)$ & 504,41 & $\mathbf{b}(\mathbf{3 1})$ & 1701,83 & $\mathbf{s}(31)$ & 0,7036 \\
\hline $\mathbf{a}(32)$ & 513,66 & b(32) & 1676,45 & $\mathbf{s}(32)$ & 0,6936 \\
\hline $\mathbf{a}(33)$ & 529,04 & b(33) & 2007,31 & $\mathrm{~s}(\mathbf{3 3})$ & 0,7364 \\
\hline$a(34)$ & 1153,74 & b(34) & 1287,85 & $s(34)$ & 0,1041 \\
\hline
\end{tabular}

$s_{\text {rata }- \text { rata }}=\frac{1}{34}(16,9203)=0,4976$

Tabel 7 menampilkan hasil keseluruhan Silhouette coefficient rata-rata semua data pada masing-masing jarak, sedangkan Gambar 2 menunjukkan grafik perbandingannya.

Tabel 7 Hasil Silhouette Coefficient Rata-rata

\begin{tabular}{|l|c|c|c|c|c|c|}
\hline Data Jarak & Euclidean & Manhattan & Chebyshev & Minkowski & Average & $\begin{array}{c}\text { Mean Character } \\
\text { Difference }\end{array}$ \\
\hline Internet & 0,533 & 0,540 & 0,521 & 0,536 & 0,533 & 0,540 \\
\hline Sayuran & 0,601 & 0,621 & 0,620 & 0,620 & 0,618 & 0,621 \\
\hline Angka Partisipasi Sekolah & 0,435 & 0,389 & 0,227 & 0,379 & 0,489 & 0,341 \\
\hline Covid-19 & 0,498 & 0,534 & 0,521 & 0,571 & 0,494 & 0,367 \\
\hline Fasilitas Sekolah & 0,498 & 0,547 & 0,524 & 0,493 & 0,498 & 0,414 \\
\hline Fasilitas Kesehatan & 0,495 & 0,464 & 0,539 & 0,522 & 0,565 & 0,464 \\
\hline
\end{tabular}




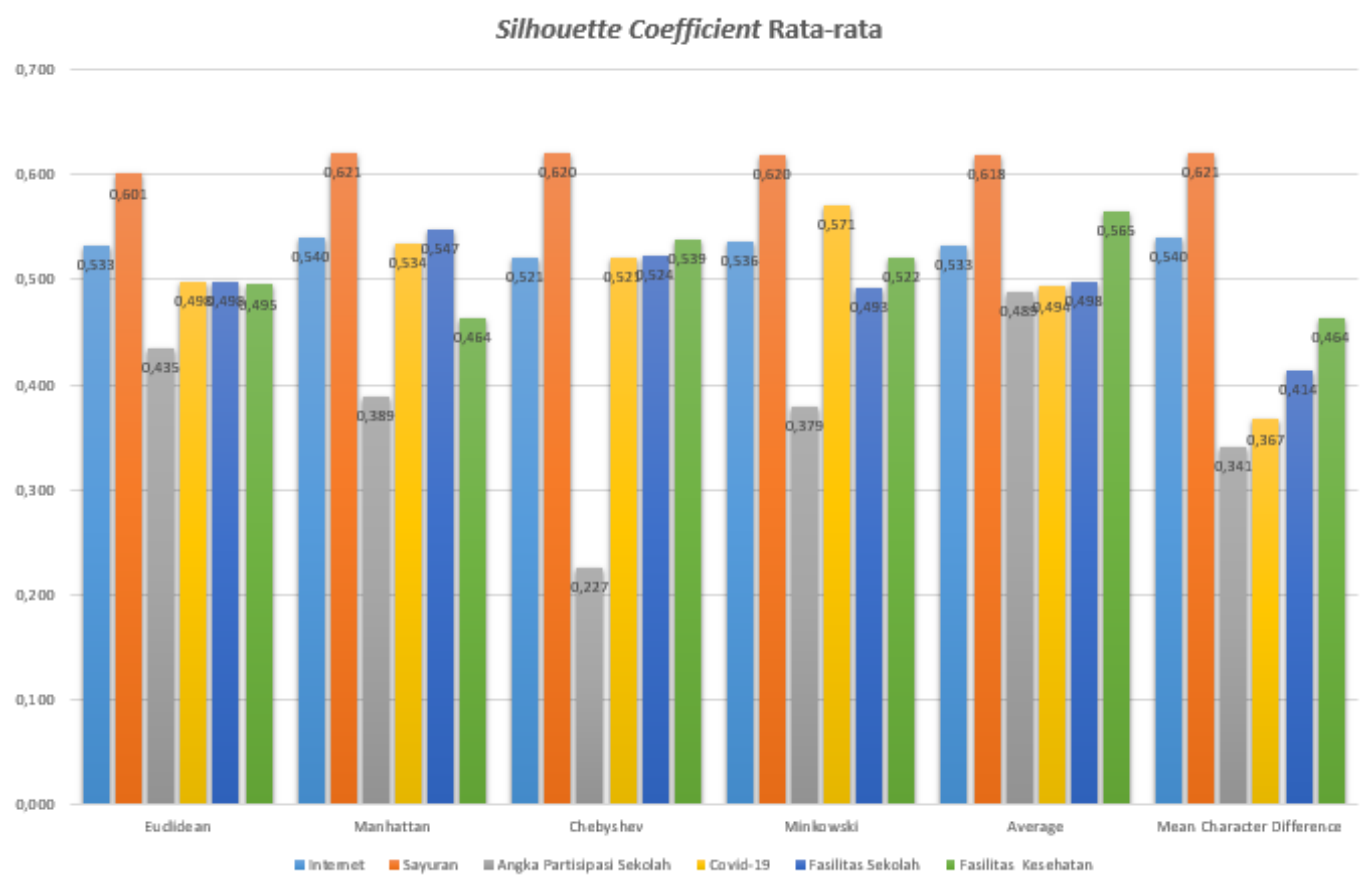

Gambar 2 Grafik perbandingan

\section{KESIMPULAN DAN SARAN}

\subsection{Kesimpulan}

Dari hasil uji perbandingan rumus jarak K-Means clustering pada 6 data yang memiliki atribut berbeda menggunakan Silhouette coefficient, dapat disimpulkan bahwa:

1) Chebyshev distance memiliki performa yang stabil baik untuk data dengan sedikit atribut maupun banyak.

2) Average distance memiliki hasil Silhouette coefficient paling tinggi dibandingkan dengan pengukuran jarak lain untuk data yang memiliki outliers seperti data 3.

3) Mean Character Difference mendapatkan hasil yang baik hanya untuk data dengan sedikit atribut.

4) Euclidean distance, Manhattan distance, dan Minkowski distance menghasilkan nilai baik untuk data yang memiliki sedikt atribut, sedangkan untuk data yang banyak atribut mendapatkan nilai cukup yang mendekati 0,5 .

\subsection{Saran}

Pada penelitian selanjutnya, pengujian hasil pengelompokan menggunakan selain Silhouette coefficient.

\section{DAFTAR PUSTAKA}

[1] J. Han, M. Kamber, Data Mining: Concepts and Techniques, Ed.2, Morgan Kaufmann, San Francisco, 2006.

[2] M. Nishom, "Perbandingan Akurasi Euclidean Distance, Minkowski Distance, dan Manhattan Distance pada Algoritma K-Means Clustering berbasis Chi-Square," Jurnal Informatika: Jurnal Pengembangan IT (JPIT), vol.04, no.01, pp. 20-24, 2019, doi: 10.30591/jpit.v4i1.1253. 
[3] M. Anggara, H. Sujiani, and H. Nasution, "Pemilihan Distance Measure Pada K-Means Clustering Untuk Pengelompokkan Member Di Alvaro Fitness," Jurnal Sistem dan Teknologi Informasi (JUSTIN), vol. 1, no. 1, pp. 1-6, 2016, [Online]. Available: https://jurnal.untan.ac.id/index.php/justin/article/view/13119/11875.

[4] I G. Harsemadi, "Perbandingan Distance Measure Pada K-Means Clustering untuk Pengelompokkan Musik Terhadap Suasana Hati," Seminar Nasional Teknologi Informasi dan Multimedia, pp. 13-18, 2018, [Online]. Available: https://ojs.amikom.ac.id/index.php/semnasteknomedia/article/view/2050.

[5] W. Gie, and D. Jollyta, "Perbandingan Euclidean dan Manhattan Untuk Optimasi Cluster Menggunakan Davies Bouldin Index: Status Covid-19 Wilayah Riau," Prosiding Seminar Nasional Riset Dan Information Science (SENARIS), vol. 2, pp.187-191, 2020, doi: http://dx.doi.org/10.30645/senaris.v2i0.160.

[6] A. Aditya, I. Jovian, and B. N. Sari, "Implementasi K-Means Clustering Ujian Nasional Sekolah Menengah Pertama di Indonesia Tahun 2018/2019," Jurnal Media Informatika Budidarma, vol. 4, no. 1, pp. 51-58, 2020, doi: 10.30865/mib.v4i1.1784.

[7] D. A. C. Rachman, R. Goejantoro, and F. D. T. Amijaya, "Implementasi Text Mining Pengelompokkan Dokumen Skripsi Menggunakan Metode K-Means Clustering," Jurnal EKSPONENSIAL, vol. 11, no. 2, pp. 167-174, 2020, [Online]. Available: http://jurnal.fmipa.unmul.ac.id/index.php/exponensial/article/view/660.

[8] A. P. Tiratana, B. Mulyawan, and M. D. Lauro, "Pembuatan Aplikasi Customer Relationship Management Berbasis Web Menggunakan Metode K-Means," Jurnal Ilmu Komputer dan Sistem Informasi, vol 7, no. 2, pp. 179-184, 2019, [Online]. Available: https://journal.untar.ac.id/index.php/jiksi/article/view/7372.

[9] C. C. B. Pradana, "Pengelompokan Data Evaluasi Pembelajaran Menggunakan Algoritma K-Means++ Clustering," Skripsi, Program Studi Teknik Informatika, Univ. Sanata Dharma, Yogyakarta, 2019.

[10] R. I. Fajriah, H. Sutisna, and B. K. Simpony, "Perbandingan Distance Space Manhattan Dengan Euclidean Pada K-Means Clustering Dalam Menentukan Promosi," Indonesian Journal on Computer and Information Technology (IJCIT), vol. 4, no. 1, pp. 36-49, 2019, doi: https://doi.org/10.31294/ijcit.v4i1.4630.

[11] F. A. Sebayang, M. S. Lydia, and B. B. Nasution, "Optimization on Purity K-Means Using Variant Distance Measure," IEEE 3rd International Conference on Mechanical, Electronics, Computer, and Industrial Technology (MECnIT), pp. 143-147, 2020, doi: 10.1109/MECnIT48290.2020.9166600.

[12] BPS-Statistics Indonesi, “Statistik Indonesia,” 2020.

[13] BPS Provinsi Jawa Timur, "Statistik Pendidikan Provinsi Jawa Timur,” 2019.

[14] http://covid19.go.id diakses Februari 2021. 
[15] G. Gan, C. Ma, and J. Wu, Data Clustering: Theory, Algorithms, and Applications, ASASIAM Series on Statistics and Applied Probability. Society for Industrial and Applied Mathematics, Alexandria, VA, 2007.

[16] A. Struyf, M. Hubert, and P. J. Rousseeuw, "Clustering in an Object-Oriented Environment," Journal of Statictical Software, vol 1, Issue 4, pp. 1-30, 1997. 